\title{
A carbon horse race: Abatement subsidies vs. permit trading in Switzerland*
}

\author{
Beat Hintermann ${ }^{\dagger}$ and Maja Žarković ${ }^{\ddagger}$
}

January 3, 2021

\begin{abstract}
Swiss climate policy consists of three regulatory instruments for greenhouse gas emissions reduction: $\mathrm{A} \mathrm{CO}_{2}$ levy, the Swiss Emissions Trading System (CH EHS) and an additional program for medium-sized plants that is labeled "nonEHS" and consists of command-and-control elements plus a sizeable abatement subsidy. Our paper informs about this tripartite climate policy, which is unique in the international context. Second, we estimate the differential impact of the $\mathrm{CH}$ EHS and the nonEHS program on plants' emissions. Our empirical strategy exploits a policy change in 2013 that instituted a mandatory emissions trading system for a subset of previously regulated plants. We find that the nonEHS outperforms the CH EHS for a minority of plants, but that on average, the two programs result in similar abatement efforts despite very different financial incentives. Plants that previously engaged in abatement efforts continue to do so even after the financial incentives were reduced by an order of magnitude.

Policy insights

- We find similar pollution abatement for plants regulated by an emissions trading system relative to plants receiving an abatement subsidy in Switzerland

- This is surprising given that the allowance price in the CH EHS is an order of magnitude lower than the abatement subsidy

- Emissions reductions in the ETS are especially pronounced for large plants, and for plants that had engaged in significant abatement in the past
\end{abstract}

Keywords: Climate policy, emissions tax, emissions trading, subsidies, command-and-control, Switzerland.

JEL codes: D22, D62, H23, H25, H32, Q52, Q54, Q58.

${ }^{*}$ This research has been supported by the WWZ Förderverein of the University of Basel. We are grateful to the Swiss Federal Office of the Environment for providing us with the required data and many helpful comments, in particular by Raphael Bucher and Silvan Aerni. We thank Armin Eberle for valuable insights and Lucas Zuckschwert and Nina Lustenberger for excellent research assistance. Any remaining errors are our own.

$\dagger$ University of Basel, Switzerland. b.hintermann@unibas.ch (corresponding author)

${ }^{\ddagger}$ University of Basel, Switzerland. maja.zarkovic@unibas.ch 


\section{Introduction}

Switzerland uses a mix of policy instruments to reduce greenhouse gas (GHG) emissions. In 2008, a $\mathrm{CO}_{2}$ levy was introduced on fossil combustion fuels. This levy was gradually increased to the current level of $\mathrm{CHF} 96$ per tCO $\mathrm{CO}_{2}$ equivalents, making it one of the highest carbon taxes worldwide. ${ }^{1}$ Not all GHG emissions from fossil fuels are subject to the $\mathrm{CO}_{2}$ levy. Importantly, transportation fuels have been exempt. Furthermore, to protect the interests of energy-intensive firms, the Swiss government has established two programs that allow individual plants to be exempt from the $\mathrm{CO}_{2}$ levy. The first program was established in 2008 and can be described as a command-and-control instrument that is combined with an abatement subsidy. It is open to plants in certain subsectors that have sufficiently high annual emissions and is known under the label nonEHS.2 In 2013, the federal government introduced an emissions trading system, called the CH EHS, which serves as another exemption mechanism from the $\mathrm{CO}_{2}$ levy.

In this paper, we exploit the sequential introduction of the nonEHS and the EHS programs to measure their differential impact on plant emissions. We focus on plants that joined the nonEHS program in 2008. Among these, a subset was transferred to the $\mathrm{CH}$ EHS in 2013, whereas the others remained in the nonEHS. This allows for the identification of the differential causal effect of these programs using a difference-in-differences framework. The empirical strategy is a consequence of data availability constraints. Since everyone is affected either by the levy or one of the two exemption programs, no valid control group exists to cleanly identify the effect of a single policy. Furthermore, the fuel use of firms and households subject to the levy is only recorded on aggregate ${ }^{3}$

Because the abatement subsidy in the nonEHS program has always been higher than the allowance price in the $\mathrm{CH}$ EHS, neoclassical economics predicts a positive treatment effect of the EHS on emissions $4^{4}$ We do find a positive effect, but only for the $\mathrm{CH}$

\footnotetext{
${ }^{1}$ The Swiss Franc is currently at parity with the US Dollar.

${ }^{2}$ EHS is the German acronym for Emissionshandelssystem, or emissions trading system.

${ }^{3}$ The levy is imposed on fossil fuels as they cross the border and thus becomes a part of the overall price. Individual purchases are only recorded if firms claim the exemption from the levy.

${ }^{4}$ In a static model, taxes and subsidies of the same magnitude result in the same equilibrium outcome because the marginal incentives are identical (Cropper and Oates, 1992). Since taxes and permits are equivalent when abstracting from uncertainty (Weitzman, 1974), the same argument applies to permits
} 
EHS plants with below-median revenue and offset generation during 2008-2012. This constitutes about a quarter of the treatment group. For all other plants, the treatment effect is not statistically significant. Our results suggest that financial incentives matter, but that other aspects (such as green preferences) may also be important drivers of firms' production and abatement decisions.

Previous research about the effectiveness of Swiss climate policy is confined to beforevs-after studies (Ecoplan, 2015, 2017), surveys of the involved firms (TEP Energy, 2016) and engineering estimates (Ecoplan, 2015; EnAW, 2019). Both the levy and the nonEHS program were found to have significantly reduced emissions, whereas the same is not clear for the CH EHS (SFAO, 2017). However, these results may be driven by unobserved heterogeneity or self-selection into the nonEHS program, as larger firms were more likely to reduce their emissions and to apply for an exemption via nonEHS. Betz et al. (2015) provide qualitative arguments as to why the multiplicity of policies makes it difficult to achieve Switzerland's overall emissions target. Landis (2019) compares the distributive implications of different recycling schemes for the revenue from the levy.

Although a clean identification of the effect of each program would be preferable, the differential impact is nevertheless interesting. There is an ongoing debate in Switzerland about whether the nonEHS program should be extended to include smaller plants. This is consistent with the theoretical prediction of firm entry into a subsidized sector over time, as subsidies increase profits whereas taxes reduce them (Kamien et al., 1966). Because moving plants from a tax to a subsidies program will result in higher program costs, such a policy would have to be justified by a superior performance of the nonEHS program in terms of emissions reductions relative to the levy. We cannot test for this directly given the available data, but we find that the nonEHS does not outperform the CH EHS. To the extent that taxes and permits are comparable, this suggests that the nonEHS likely will not outperform the levy either.

Our analysis contributes to the political discussion about climate policy, in particular in Switzerland but more generally about the choice between permits (or taxes) vs. subvs. subsidies. 
sidies. Because of the theoretical equivalence of taxes, permits and subsidies, the choice between these instruments can include additional policy considerations such as trade competitiveness and equity concerns (Conrad, 1993; Nault, 1996) or the market structure of the supply chain (Bian and Zhao, 2020). In the political process, subsidies for "good behavior" are often more easy to implement than taxes on pollution (see, e.g., Brannlund and Persson, 2012; Cherry et al., 2012, Carattini et al., 2017). Furthermore, there may be differences between "carrots" and "sticks" from a behavioral perspective if their salience differs (Galle, 2013). Since subsidy payments may be more visible than tax savings on reduced emissions, it is possible that imperfectly informed firm managers respond more to abatement subsidies than to an equivalent $\mathrm{CO}_{2}$ tax. This has been proposed as a benefit of the nonEHS program. However, we do not find evidence for this hypothesis.

In the next section, we provide background information about Swiss climate policy. Section 3 describes our identification strategy and the data, and section 4 presents the results. Section 5 offers concluding remarks.

\section{Swiss climate policy}

Swiss climate policy is based on the Federal Act on the Reduction of $\mathrm{CO}_{2}$ Emissions (" $\mathrm{CO}_{2}$ Act"), which has been updated several times since its inception in 2000. The $\mathrm{CO}_{2}$ Act prescribes a variety of policy measures that were further specified in different action plans, programs and policies. The current version of the $\mathrm{CO}_{2}$ Act was implemented on January 1, 2013. More information about the revised $\mathrm{CO}_{2}$ Act and Swiss climate policy can be found on the website of the Federal Office of the Environment (FOEN) $5^{5}$ and in Hintermann and Zarkovic (2020). In what follows, we briefly describe those policies of the $\mathrm{CO}_{2}$ Act that are relevant to our context.

\footnotetext{
5 https://www.bafu.admin.ch/bafu/en/home/topics/climate/info-specialists/ climate-policy.html.
} 


\subsection{The CO2 Levy}

Since 2008, Switzerland has imposed a $\mathrm{CO}_{2}$ levy on fossil heating and process fuels. Transport fuels have been exempted from the $\mathrm{CO}_{2}$ levy from the very beginning. Instead, a surcharge of one cent/liter was added to all gasoline and diesel imports ${ }^{6}$ The levy is collected at the border crossing (there are no fossil fuels produced in Switzerland). Two thirds of the collected revenue are redistributed to taxpayers and firms, whereas the remainder is used to subsidize investments in building efficiency.

The $\mathrm{CO}_{2}$ Act defined interim reduction targets for emissions from thermal fuels. Nonattainment of the targets triggers an automatic increase in the $\mathrm{CO}_{2}$ levy in multiples of CHF 12 per metric ton of $\mathrm{CO}_{2}$ equivalents. The current tax is $\mathrm{CHF} 96 / \mathrm{tCO}_{2}$. Table A.1 in the appendix shows the levy since its introduction, along with the (international) exchange prices for four types of fuels and the corresponding surcharges due to the levy.

Figure 1: Aggregate emissions from combustion and transportation

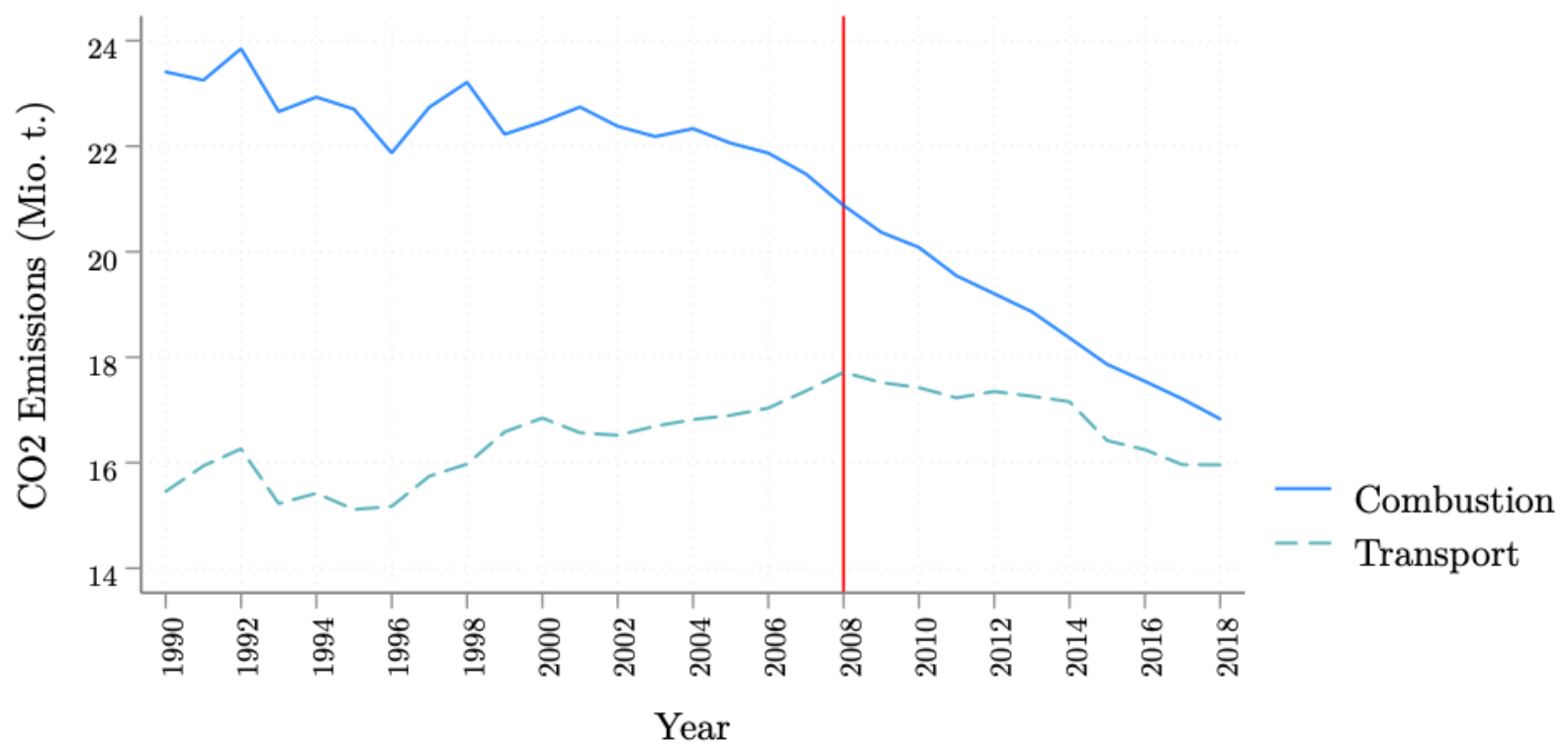

Source: Own illustration based on data from the Swiss greenhouse gas inventory

Figure 1 indicates that, unlike emissions from transport, aggregate combustion emissions have significantly decreased in Switzerland, suggesting that the $\mathrm{CO}_{2}$ Act has had some effect. However, it is not clear to what extent each instrument of the $\mathrm{CO}_{2}$ Act has contributed to the emissions reduction, including the effect of the subsidies that are

\footnotetext{
${ }^{6}$ The surcharge has been increased to 4.5 cents/liter, which translates to a $\mathrm{CO}_{2}$ tax for transport fuels of $20 \mathrm{CHF} / \mathrm{tCO}_{2}$.
} 
financed with the proceeds of the $\mathrm{CO}_{2}$ levy. A part of the decrease may have been due to general technological progress, as the reduction in emissions started before 2008.

A series of reports commissioned by FOEN (Ecoplan, 2015, 2017) examine the effect of the $\mathrm{CO}_{2}$ tax on firms and households by means of a time series analysis and a computable general equilibrium model. They estimate that the levy led to a reduction of 6.9 million tons of $\mathrm{CO}_{2}$ for the 2008-2015 period, which corresponds to $4.4 \%$ of the combustion emissions 7

\subsection{The nonEHS program}

The nonEHS program is an emissions intensity target program coupled with commandand-control elements and an abatement subsidy. For the purposes of our analysis, we assume that the nonEHS was instituted in 2008, even though it initially had a different name 8 Plants with a high emissions tax burden in relation to their value, and whose international competitiveness would be significantly undermined as a result, can participate in the nonEHS program and thus be exempt from paying the $\mathrm{CO}_{2}$ levy. Although the exemption takes place on the plant-level, nonEHS participants can form groups, such that firms can aggregate their plants and participate as a single entity.

To apply to the nonEHS program, plants have to develop a set of specific emissions measures and reduction goals, which is done in cooperation with specialized business associations $9^{9}$ If approved by FOEN, this abatement plan forms the basis for a formal and individualized target agreement. Only abatement measures that are deemed "economically viable" are included in the agreements, with a payback period between 4 and 8 years (FOEN, 2018, p.80).

Plants are free to choose measures that go beyond those specified in the agreement,

\footnotetext{
${ }^{7}$ Total GHG emissions in Switzerland in the years 2008-2015 amounted to 411 million tons of $\mathrm{CO}_{2}$, of which 155 million tons were subject to the $\mathrm{CO} 2$ tax. Source: Swiss greenhouse gas inventory, available at https://www.bafu.admin.ch/bafu/en/home/topics/climate/state/data/ greenhouse-gas-inventory.html.

"The program was introduced in 2008 under the label "CH EHS". This term was replaced by the term "nonEHS" in 2013 to differentiate it from the CH EHS.

${ }^{9}$ These are the "Energieagentur der Wirtschaft" (EnAW) and the "Cleantech Agentur Schweiz" (act). There are two versions of the nonEHS. The first is based on emissions goals along with abatement measures and applies to larger plants, whereas the second version only includes a definition of measures that a plant has to implement. In this paper, we focus on the "emissions goal" version.
} 
but the specified measures are compulsory; this is the "command-and-control" part of the program. If plants exceed their targets, they can sell the surplus in the form of offsets to a foundation that uses them to compensate emissions from the transport sector. The price paid before 2013, in other words, the abatement subsidy, was determined in a series of auctions and ranged between 40 and $100 \mathrm{CHF} / \mathrm{tCO}_{2} \cdot 10$ Since 2013, the abatement subsidy has been fixed at $\mathrm{CHF} 100 / \mathrm{tCO}_{2}$.

In theory, the system is symmetric in the sense that plants could purchase these domestic offsets if they fall short of their goals. In practice, however, this never happens because (i) the abatement goals are chosen such that they can be achieved with the mandatory measures, (ii) shocks in product demand (and thus emissions) are neutralized by benchmarking, (iii) plants were allowed to count a limited number of international offsets towards achieving their emission targets (FOEN, 2019a) and (iv) plants were allowed to transfer emissions over time such that a shortfall in one year can be offset by a surplus in the next. As a consequence, nonEHS plants exclusively act as suppliers of offsets and are thus effectively subsidized for their (marginal) abatement efforts.

A study commissioned by FOEN (TEP Energy, 2016) surveyed firms subject to the tax or one of the exemption mechanisms with respect to climate-relevant decision making. Firms with exempt plants reported more abatement measures, on average, than firms paying the tax. Since larger firms and firms with a higher emission intensity were both more likely to seek exemption and to engage in significant abatement measures, these results could be explained by self-selection. Firms that chose not to apply for an exemption explained this with the significant transaction costs associated with developing a target agreement. Similar results have been reported by Krysiak and Oberauner (2010).

EnAW (2019) estimated that the agreements with the nonEHS plants imply an increase in emissions intensity, relative to the base year 2012, of $4.7 \%$ by 2018 and of $8.4 \%$ by 2022. As shown in Figure 2, the nonEHS plants over-achieved these reduction goals, such that by 2018, the actual emission intensity had been decreased by $11.7 \%$ (dashed line). These numbers should be viewed with caution, however, as some of the involved

\footnotetext{
${ }^{10}$ The clearing prices paid per $\mathrm{tCO}_{2}$ were CHF 70 in 2007, CHF 100 in 2009 and CHF 40 in 2012 (Climate Cent Foundation, 2013).
} 
abatement measures would have happened anyway. An external evaluation concluded that only 20-40\% of the emission reductions were caused by the agreement and the subsidies, whereas the remainder would have happened anyway.

Figure 2: Emission intensity for plants with emissions goals

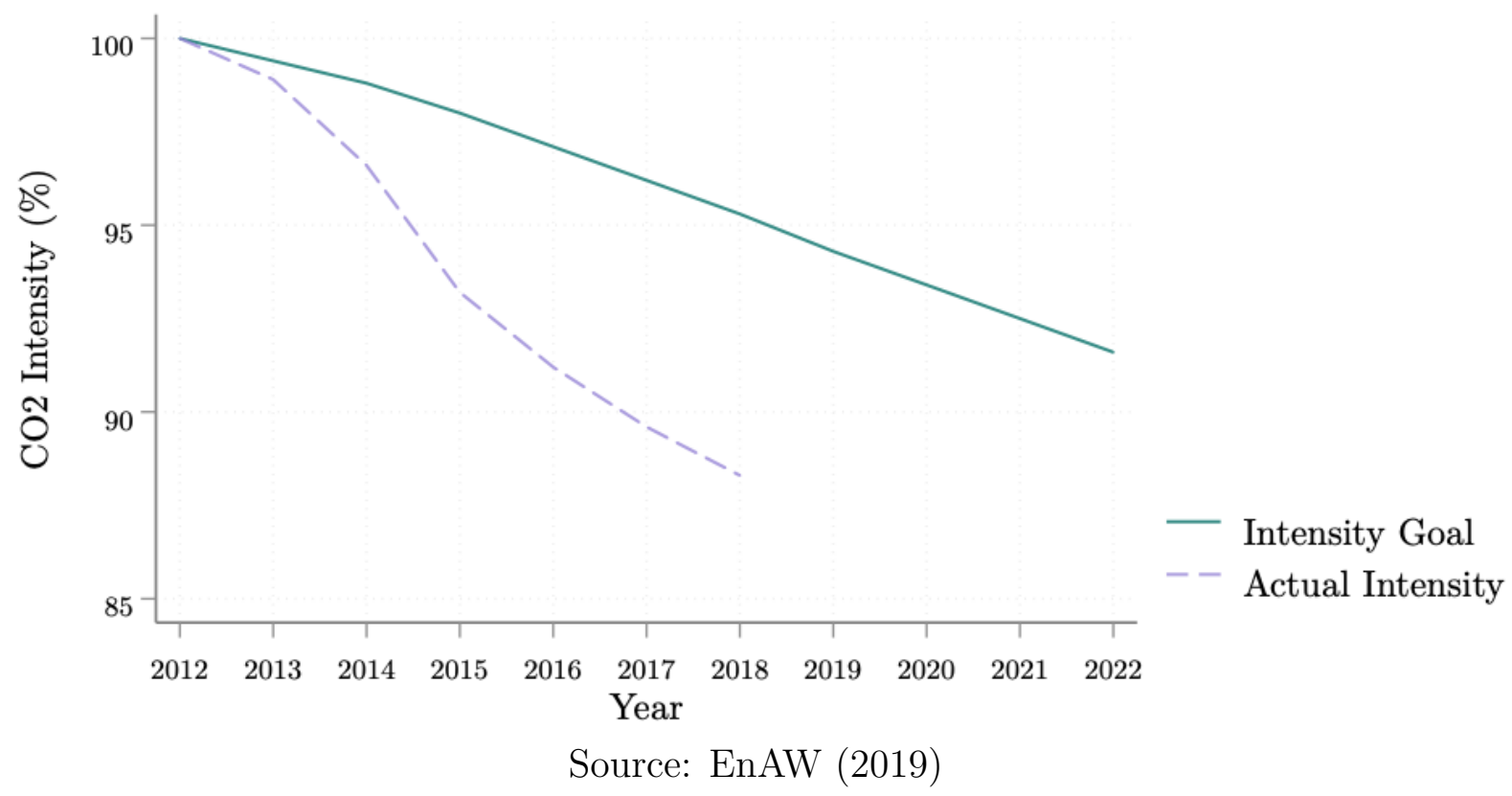

From 2008 to 2018, nonEHS plants emitted a total of 23.7 million tCO $\mathrm{CO}_{2}$. Multiplied by the levy that applied at the time of the emission, this leads to a foregone tax revenue of CHF 1,017 million.11 In addition, the federal government spent CHF 296 million to compensate firms for over-abatement. In addition to these monetary program costs, additional costs accrue when defining target agreements and monitoring firms' compliance.

\subsection{The CH EHS}

The CH EHS in its current form was introduced in 2013. All relevant parameters have been aligned with those of the EU emissions trading system (EU ETS). Participation in the $\mathrm{CH}$ EHS is mandatory for plants with a total rated thermal input above 20 MW. Additional thresholds apply to certain sectors based on production capacity. In sectors

\footnotetext{
${ }^{11}$ Because the revenue from the $\mathrm{CO}_{2}$ levy is returned to firms and households, the federal government does not actually have less operating revenue if an additional plant is exempt. Nevertheless, having the revenue is associated with a social benefit: A third of it is used to fund energy efficiency programs in the building sector, and returning the remaining two thirds to firms and households increases redistribution. The government thus loses the ability to subsidize and redistribute income as a consequence of exempting more firms.
} 
that tend to be dominated by large installations (e.g., refining of mineral oil or production of steel), all plants are included. Due to the absence of fossil-based power generation in Switzerland, only a few plants fulfill these criteria.

In theory, plants with an installed thermal input capacity between 10 and $20 \mathrm{MW}$ are allowed to opt into the CH EHS. However, there were only four plants that did so, all of which are owned by firms that have other plants that are included in the CH EHS by law. We assume that the opt-in was motivated by a desire to limit the transaction costs of having to comply with two different regulatory environments rather than due to an unobserved propensity to abate emissions.12 Subject to this assumption, the treatment can be interpreted to be exogenous. Currently, the CH EHS includes 53 plants belonging to 36 different firms.

The CH EHS uses harmonized allocation rules based on the benchmarks used in the EU ETS. About $95 \%$ of the cap is allocated for free and the remainder retained as a reserve. Figure 3 shows the total emissions cap (solid line), along with emissions and free allocation (bars). Changes in the free allocation due to adjustments in the production capacity or of entry and exit of plants, do not affect the overall cap but are taken from (or added to) the reserve.

Figure 3: Cap, emissions and allowance price in the $\mathrm{CH}$ EHS

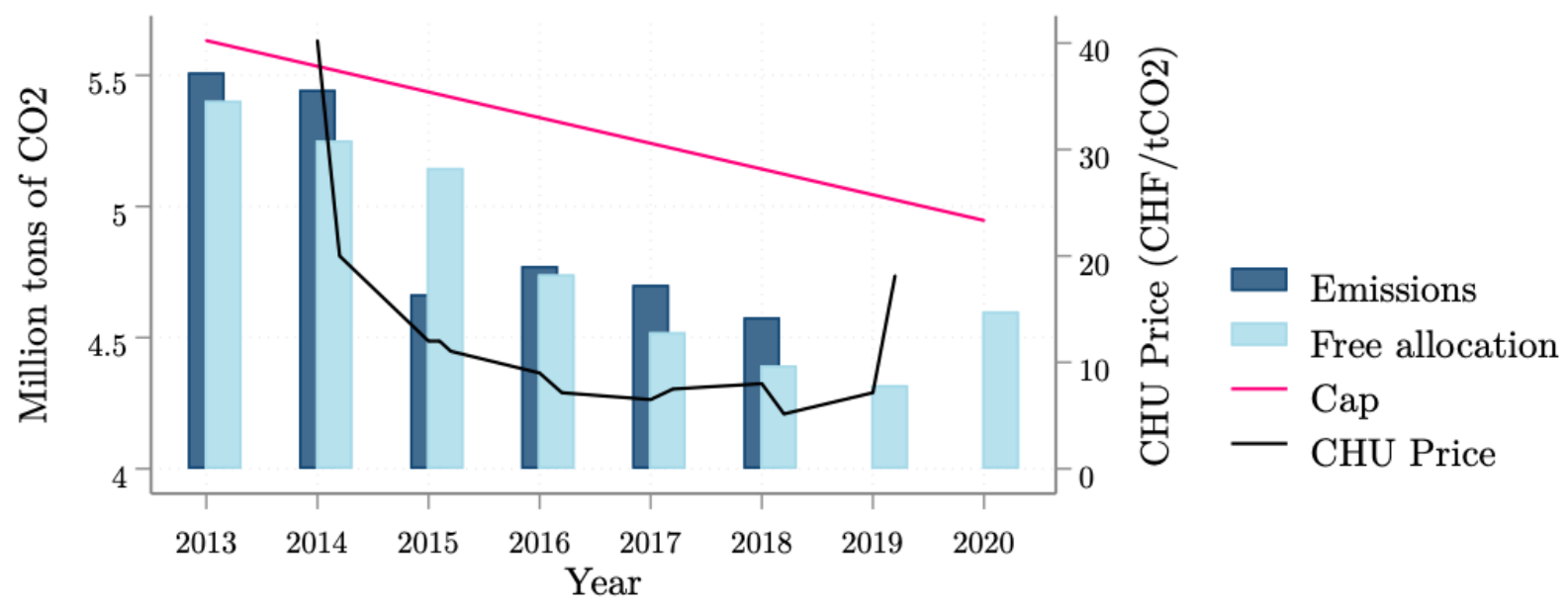

Source: Own illustration based on the data from the FOEN (2019) and the Swiss Emissions Trading Registry (https://www.emissionsregistry.admin.ch).

The unused allowance reserve is sold in the following year in bi-annual auctions. The

\footnotetext{
${ }^{12}$ The results remain qualitatively unchanged when removing these plants from the analysis.
} 
auction in May 2014 established the first price for CH EHS emission allowances. As no secondary allowance market has emerged, the auctions have remained the sole source of a price signal. The auction price is shown in Figure 3 .

The CH EHS was evaluated by the Swiss Federal Audit Office (SFAO, 2017) and found to be over-allocated in terms of emission allowances and plagued by low liquidity. The allowance price was deemed too low to induce meaningful abatement activities. Despite these shortcomings, we note that emissions in the CH EHS did decrease over time, as can be seen in Fig 3. Between 2013 and 2018, the total emissions within the CH EHS decreased by $17 \%$.

\subsection{Cantonal regulation}

Swiss cantons have far-reaching regulatory autonomy. However, the cantonal governments have agreed on a "lowest common denominator" for energy policy. This basic compromise is known as the "large user model" (Grossverbrauchermodell in German, or GVM) and states that all cantons should regulate plants that use more than $5 \mathrm{GWh}$ of heat input and/or 0.5 GWh of electricity per year ${ }^{13}$ Plants can choose one of three pathways to implement the GVM: (1) work out energy efficiency measures with EnAW or Swiss Cleantech, just like nonEHS plants (see above); (2) develop an agreement with the canton in which they operate; and (3) carry out an energy audit.

The GVM does not focus on emissions but on energy efficiency, and in particular on electricity use. The overlap with the CH EHS is therefore limited. Furthermore, most cantons do not require very stringent energy efficiency measures in order not to disadvantage "their" firms relative to competitors in other cantons and abroad. Nevertheless, it is possible that plants in the CH EHS have reduced emissions, among other reasons, due to the measures developed under the GVM, and we therefore control for GVM coverage in our regressions.

\footnotetext{
${ }^{13}$ More information about the GVM can be found at https://www.endk.ch/de/ energiepolitik-der-kantone/grossverbrauchermodell.
} 


\section{Methodology and data}

In this section, we first describe our identification strategy and then present the data.

\subsection{Research design}

Our design exploits the facts that despite the name change, the main parameters of the nonEHS program have remained stable since its introduction in 2008, and that many of the plants currently in the CH EHS used to be in the nonEHS program. We estimate the differential effect of these two programs using a difference-in-differences (DiD) approach. The control group consists of the plants that have remained in the nonEHS program throughout, whereas the treatment plants are those that were transferred from the nonEHS program to the CH EHS in the beginning of 2013. Because inclusion into the EHS was mandatory for plants that exceed the thermal input threshold, the treatment is arguably exogenous ${ }^{14}$

Comparing the emissions in the two groups allows for a causal identification of the differential effect. Based on the higher financial incentive for emissions reductions, we would expect the nonEHS to result in more emissions abatement.

Our base specification consists of a difference-in-differences (DiD) analysis of the log of emissions, such that we measure which group reduced emissions by a larger proportion. We estimate the following equation:

$$
e_{i t}=c_{i}+c_{t}+\alpha \cdot D i D_{i t}+\epsilon_{i t}
$$

where $e_{i t}$ refers to the natural logarithm of $\mathrm{CO}_{2}$ emissions of plant $i$ in year $t, c_{i}$ to a plant-level fixed effect, $c_{t}$ to a vector of yearly dummies and $\epsilon_{i t}$ is an i.i.d. error term. The coefficient of interest is $\alpha$, which multiplies the difference-in-difference term $D i D_{i t} \equiv$ $D_{t} \cdot D_{i}$, where $D_{i}$ refers to the treatment group dummy and $D_{t}$ to the treatment period

\footnotetext{
${ }^{14}$ As noted above, four plants opted into the CH EHS even though they did not meet the mandatory inclusion requirement. However, all four plants belong to firms that owned other plants for which inclusion in the EHS was mandatory. Presumably, the transactions costs of being part of two separate programs was deemed sufficiently large for these firms to place all of their plants into the system, despite the financial incentives of remaining in the nonEHS for individual plants.
} 
dummy. We allow the errors to be correlated within plants belonging to the same firm.

To investigate a potential effect heterogeneity across plants, we allow the treatment effect to vary across pre-treatment characteristics $Z_{0 i}$ :

$$
e_{i t}=c_{i}+c_{t}+\alpha \cdot D i D_{i t}+\gamma \cdot D i D_{i t} \cdot Z_{0 i}+\epsilon_{i t}
$$

Rather than continuous variables, we use dummies denoting bins of the distribution, such that the treatment effect for a particular bin will be given by $\alpha+\gamma$.

In addition to a simple comparison of (log) means, we employ a matched-control analysis similar in spirit to Fowlie et al. (2012) and Wagner et al. (2014), where we compare treated plants to control plants that are similar with respect to pre-treatment characteristics. We match exactly on the 1-digit industry classification 15 as well as parametrically on the pre-treatment level of revenue, employment and capital. The matching procedure reduces our sample to plants in the manufacturing sector. The industrial composition of the full and matched samples is shown in Table A.2 in the Appendix. To control for potentially different trajectories, we also match on the proportional emissions reduction during the pre-treatment period. Because there may be anticipation effects, we only use information from the years 2008-2011 for matching.

We start by matching to the nearest neighbor without replacement, where we allow for error clustering on the matched pairs. To test for the robustness of the results, we also engage in matching with replacement, in which we vary the number of matched control plants per treated plant between 1 and 5 and bootstrap the standard errors.

\subsection{Data}

Total reported emissions from plants in the nonEHS and EHS programs in the period 2008-2012 are available from the public reports published in the Swiss Emissions Trading Registry. However, emissions reported for the period 2008-2012 are not directly comparable with emissions reported since 2013 for several reasons.

\footnotetext{
${ }^{15}$ Exact matching on 2 digits would lead to very few matched observations. Also, we do not have industry classification beyond the first digit for all control plants.
} 
First, the perimeter of the covered emissions has changed. During 2018-2012, only the emissions from eight "standard" fuels were considered ${ }^{16}$ but since 2013, a number of process and waste emissions have also been included. To make the data comparable, we focus on plant emissions from the eight standard fuels for the entire sample period and apply a constant emission factor for the entire period. Second, emissions from purchased heat have been counted as the heat producers' emissions since 2013, but had been assigned to the buyer before that. To circumvent this problem, we identify the emissions associated with the heat purchases in 2008-2012 and associate them with the producers throughout our sample period. And last, plants are allowed to participate in groups in both the $\mathrm{CH}$ EHS and the nonEHS program. Some groups dissolved with the policy change, whereas new groups were formed in 2013. We aggregate the emissions to the largest group level before and after 2013 .

To carry out these adjustments, we relied on the help and expertise of the FOEN staff who provided us with a complete data set based on a comparable emissions perimeter from the eight standard fuels.

We complement the emissions data with information on employment, capital and revenue from Bureau van Dijk's Orbis database. The Orbis data are on the firm-level. To assign the quantities to individual plants, we used additional information from business reports. Where no such information is available, we simply divide the firm-level information equally among the number of plants.

Table 1 presents summary statistics of our 26 treated and 186 control plants (or group of plants, if participating jointly) over the 11-year period. The EHS plants are significantly larger in all dimensions. Constant differences are accounted for by the plant-level fixed effects and therefore pose no problem for identification, but we have to account for the possibility that very emission-intensive plants may have different abatement trajectories than plants for which emissions account for only a small share of total costs. This is the reason for including the proportional reduction of emissions during the pre-treatment years among our matching variables (see above).

\footnotetext{
${ }^{16}$ These are lignite, hard coal, propane, butane, natural gas, gas-oil, extra light fuel oil, medium/heavy heating oil and coke.
} 
Table 1: Summary statistics

\begin{tabular}{|c|c|c|c|c|c|c|}
\hline & $\begin{array}{c}\text { Observations } \\
(\mathrm{Nr} .)\end{array}$ & $\begin{array}{l}\text { Emissions } \\
\left(\mathrm{Mt} \mathrm{CO}_{2} / \mathrm{y}\right)\end{array}$ & $\begin{array}{c}\text { Revenue } \\
\text { (million CHF/y) }\end{array}$ & $\begin{array}{c}\text { Employees } \\
\text { (Full-time eq.) }\end{array}$ & $\begin{array}{c}\text { Capital } \\
\text { (million CHF/y) }\end{array}$ & $\begin{array}{c}\text { Offsets } \\
\left(\mathrm{Mt} \mathrm{CO}_{2}\right)\end{array}$ \\
\hline All plants & 2,332 & 8.043 & 429.124 & 923 & 13.831 & 11.661 \\
\hline Treated & 286 & & & & & \\
\hline 2008-2012 & 130 & 51.398 & $2,343.757$ & 5,586 & 67.517 & 48.907 \\
\hline 2013-2018 & 156 & 41.593 & $2,398.359$ & 5,485 & 76.306 & 0 \\
\hline Control & 2,046 & & & & & \\
\hline 2008-2012 & 930 & 2.929 & 131.137 & 252 & 4.819 & 3.894 \\
\hline 2013-2018 & 1,116 & 2.406 & 135.489 & 223 & 4.861 & 2.560 \\
\hline
\end{tabular}

Notes: Offsets correspond to the total amount of over-abatement sold to CCF and KliK generated during 2008-2018.

Average annual emissions of the treated and control plants are shown in Figure 4, with and without matching on observable characteristics. The vertical line in 2012 marks the last year before the treatment. Because the emission levels differ significantly between the two groups, we plot the emission trends on different axes.

Figure 4: Emissions before (left) and after (right) matching

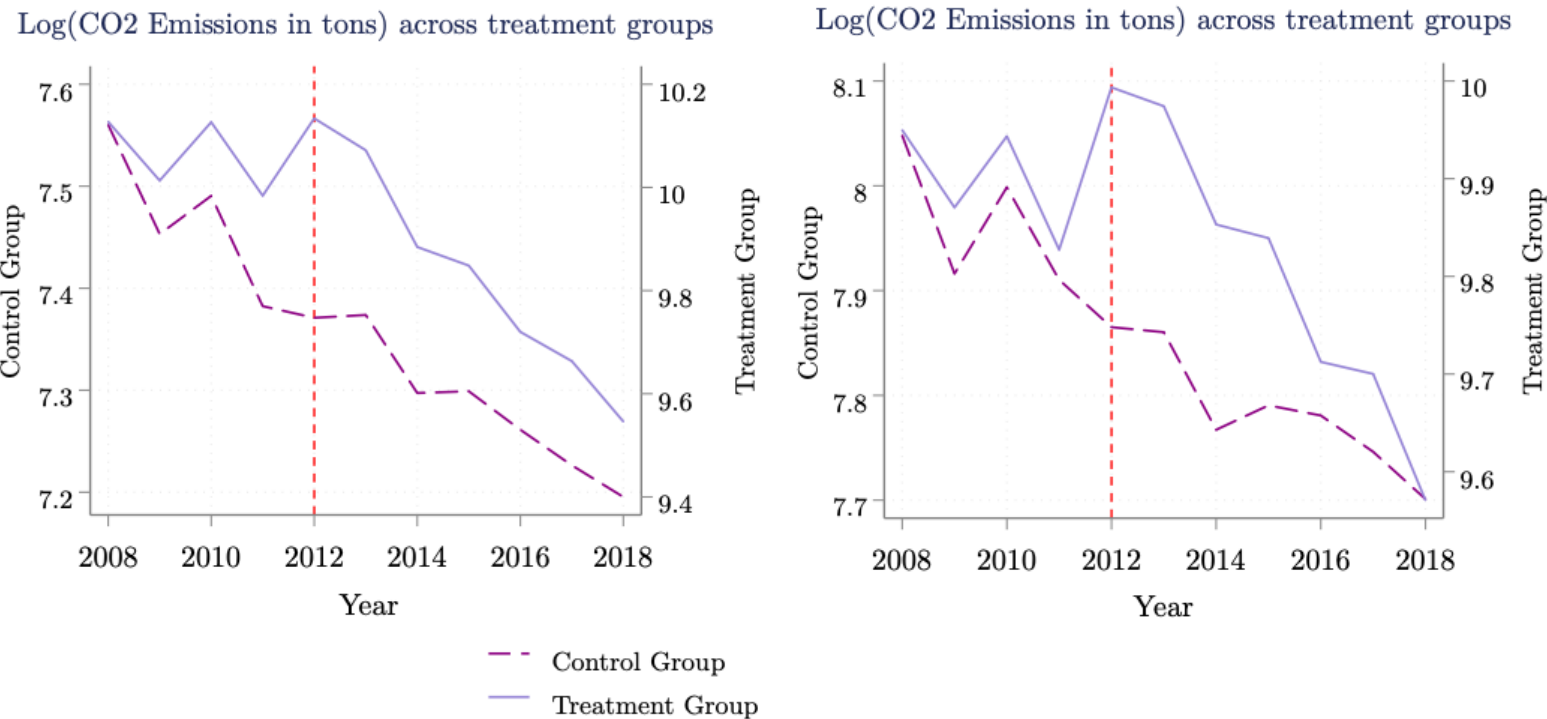

The figure highlights two important facts. First, matching matters. The trends prior to 2013 are much more similar once we condition on pre-treatment characteristics. When interpreting our findings, we will therefore place more weight on the results from the matched analysis. Second, the year 2012 is special in the sense that the treatment group 
temporarily increased its emissions relative to the control plants ${ }^{17}$ To avoid creating a bias from such anticipation effects, we exclude the year 2012 from our analysis. The average treatment effect that we estimate will therefore be based on a comparison of the years 2008-2011 (pre-treatment) and the years 2013-2018 (post-treatment).

\section{Results}

Table 2 presents the results from estimating equation (1). The model in the first column includes industry dummies and controls for pre-treatment characteristics on the plantlevel. In addition to the variables used for matching, we also include the level of pretreatment emissions and the number of offsets generated during 2008-2012. To control for a potential impact of cantonal regulation, we include a dummy that denotes active regulation subject to the GVM (and which is zero otherwise). This dummy only applies to EHS plants, as all nonEHS plants fulfill the GVM rules by construction.

Plant emissions increase with the average level of pre-treatment emissions and revenue, whereas the effect of the other variables is not significant at $\mathrm{p}<0.05$. However, this regression may be influenced by omitted variables that drive emissions, and which are correlated with observed plant characteristics. To control for (constant) unobserved heterogeneity, we include plant-level fixed effects in all other regressions.

Column (2) presents the result from a difference-in-differences estimation involving all plants. In columns 3-5, we compare treated with matched control plants based on different forms of matching. In all regressions, the estimate for the average treatment effect is not statistically significant. This is surprising given the different financial incentives for abatement in these two programs. However, we note that due to our sample size, the standard errors are large such that a small differential effect cannot be ruled out.

Figure 5 illustrates the results in the format of an event study. We see that the average

\footnotetext{
${ }^{17}$ The statistically significant but temporary surge in emissions for plants that joined the CH EHS in 2013 could be due to various reasons. For example, plants could have increased their emissions in the hope to obtain more free allocation, or to "use up" their surplus accumulated during the previous years in the belief that it could not be transferred into the treatment period. In fact, free allocation was not based on emissions in 2012 and plants could in fact sell their over-abatement from 2008-2012 even in the post-treatment years. However, this may not have been clear for all plants.
} 
Table 2: Treatment effect (full sample and matched sample)

\begin{tabular}{|c|c|c|c|c|c|}
\hline \multirow[t]{2}{*}{ Dependent Variable: } & \multicolumn{5}{|c|}{ Emissions in tons of $\mathrm{CO} 2$ in logs } \\
\hline & $\begin{array}{c}(1) \\
\text { no matching }\end{array}$ & $\begin{array}{c}(2) \\
\text { no matching }\end{array}$ & $\begin{array}{c}\text { (3) } \\
\mathrm{NN} \text { w./o. repl. }\end{array}$ & $\begin{array}{l}(4) \\
\text { N3N w. repl. }\end{array}$ & $\begin{array}{c}\text { (5) } \\
\text { N5N w.repl. }\end{array}$ \\
\hline DiD & $\begin{array}{c}0.070 \\
(0.623)\end{array}$ & $\begin{array}{l}-0.071 \\
(0.632)\end{array}$ & $\begin{array}{c}0.108 \\
(0.368)\end{array}$ & $\begin{array}{c}0.157 \\
(0.129)\end{array}$ & $\begin{array}{c}0.114 \\
(0.220)\end{array}$ \\
\hline Emissions ave. & $\begin{array}{c}0.945^{* * *} \\
(0.000)\end{array}$ & & & & \\
\hline Emissions trend & $\begin{array}{c}0.342^{* *} * \\
(0.018)\end{array}$ & & & & \\
\hline Revenue & $\begin{array}{c}0.049 * * * \\
(0.002)\end{array}$ & & & & \\
\hline Capital & $\begin{array}{l}-0.015 \\
(0.344)\end{array}$ & & & & \\
\hline Employment & $\begin{array}{c}-0.043^{* * *} \\
(0.018)\end{array}$ & & & & \\
\hline Offsets & $\begin{array}{l}-0.005 \\
(0.211)\end{array}$ & & & & \\
\hline Cantonal regulation & $\begin{array}{c}0.119 \\
(0.404)\end{array}$ & & & & \\
\hline Industry dummies & $\checkmark$ & $x$ & $x$ & $x$ & $x$ \\
\hline Year FE & $\checkmark$ & $\checkmark$ & $\checkmark$ & $\checkmark$ & $\checkmark$ \\
\hline Plant FE & $x$ & $\checkmark$ & $\checkmark$ & 2 & $\checkmark$ \\
\hline Obs. & 1720 & 2066 & 433 & 568 & 727 \\
\hline
\end{tabular}

Note: ${ }^{*} p<0.10,{ }^{* *} p<0.05,{ }^{* * *} p<0.01$. (1) and (2): Standard errors (in parentheses) are clustered on the firmlevel. (3): Standard errors (in parentheses) are clustered on the matched-pair level. (4) and (5): Standard errors (in parentheses) are obtained through bootstrapping (500 replications). "Emissions trend" refers to the (log) difference of emissions in 2010-2011 and 2008-2009. "Offsets" refers to the ratio between the offsets generated by over-abatement and plants' total emissions during 2008-2012.

treatment effect is far from being significant in all years, and that there are no pretreatment effects in the years 2008-2011. In fact, the point estimate is negative, making it unlikely that the EU ETS increased emissions relative to the nonEHS program.

To investigate whether the absence of an overall effect masks heterogeneous responses by different types of plants, we interact the DiD term with pre-treatment information as specified in eq. (2). We include dummies that take the value of one if a plant exhibits an above-median value for a particular pre-treatment variable, and zero otherwise.

The results from this analysis are presented in Table 3 . All regressions in this table are based on nearest-neighbor matching without replacement, but the qualitative results are robust to different matching procedures, and to using continuous pre-treatment variables (rather than dummmies); see Table A.6 in the appendix. Columns (1)-(6) individually include different pre-treatment variables. For some specifications, the treatment effect is positive and significant. This effect applies to plants that exhibit below-median values for the respective pre-treatment variable (offsets, average emissions and revenue). The treatment effect for plants with above-median values is the sum of the coefficients on the 


\section{Figure 5: Event Study}

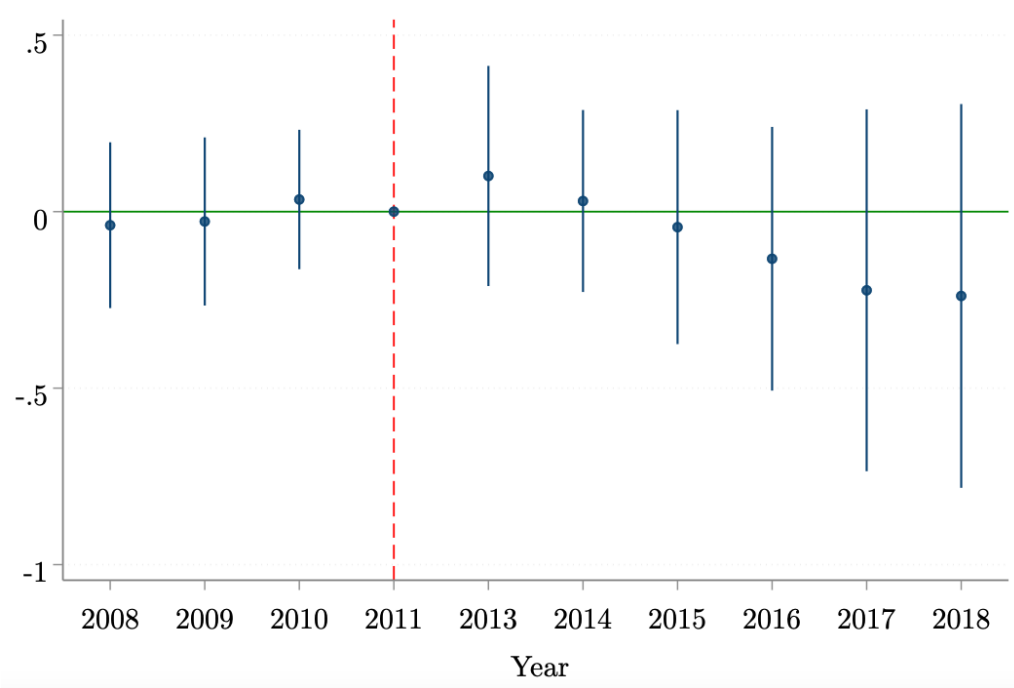

DiD term and on the interaction term, which is not statistically significant for any model.

The treatment effect is not driven by the cantonal regulation, as neither the coefficient on the DiD term nor its sum with the interaction coefficient is significant.

Table 3: Treatment effect (matched sample)

\begin{tabular}{|c|c|c|c|c|c|c|c|c|c|}
\hline \multirow[t]{3}{*}{ Dependent Variable: } & \multicolumn{9}{|c|}{ Emissions in tons of $\mathrm{CO} 2$ in logs } \\
\hline & (1) & (2) & (3) & (4) & $(5)$ & (6) & (7) & (8) & (9) \\
\hline & & & & Matching & without 1 & eplacement & & & \\
\hline DiD & $\begin{array}{c}0.265^{* *} \\
(0.035)\end{array}$ & $\begin{array}{l}0.237^{*} \\
(0.053)\end{array}$ & $\begin{array}{c}0.020 \\
(0.872)\end{array}$ & $\begin{array}{l}0.216^{*} \\
(0.081)\end{array}$ & $\begin{array}{c}0.177 \\
(0.122)\end{array}$ & $\begin{array}{c}0.085 \\
(0.438)\end{array}$ & $\begin{array}{c}0.068 \\
(0.668)\end{array}$ & $\begin{array}{c}0.379^{* * *} \\
(0.001)\end{array}$ & $\begin{array}{c}0.373^{* * *} \\
(0.001)\end{array}$ \\
\hline DiD x Offsets & $\begin{array}{c}-0.317^{* *} \\
(0.030)\end{array}$ & & & & & & & $\begin{array}{l}-0.284^{*} \\
(0.060)\end{array}$ & $\begin{array}{c}-0.318^{* *} \\
(0.020)\end{array}$ \\
\hline DiD x Emissions ave. & & $\begin{array}{c}-0.285^{*} \\
(0.051)\end{array}$ & & & & & & $\begin{array}{l}-0.090 \\
(0.467)\end{array}$ & \\
\hline DiD x Emissions trend & & & $\begin{array}{c}0.173 \\
(0.246)\end{array}$ & & & & & & \\
\hline DiD x Revenue & & & & $\begin{array}{l}-0.236 \\
(0.111)\end{array}$ & & & & $\begin{array}{l}-0.197^{*} \\
(0.089)\end{array}$ & $\begin{array}{l}-0.237^{*} \\
(0.075)\end{array}$ \\
\hline DiD x Capital & & & & & $\begin{array}{l}-0.150 \\
(0.335)\end{array}$ & & & & \\
\hline DiD x Employment & & & & & & $\begin{array}{c}0.046 \\
(0.764)\end{array}$ & & & \\
\hline DiD x Cantonal regulation & & & & & & & $\begin{array}{c}0.084 \\
(0.512)\end{array}$ & & \\
\hline Year FE & $\checkmark$ & $\checkmark$ & $\checkmark$ & $\checkmark$ & $\checkmark$ & $\checkmark$ & $\checkmark$ & $\checkmark$ & $\checkmark$ \\
\hline Plant FE & $\checkmark$ & $\checkmark$ & $\checkmark$ & $\checkmark$ & $\checkmark$ & $\checkmark$ & $\checkmark$ & $\checkmark$ & $\checkmark$ \\
\hline Obs. & 433 & 433 & 433 & 433 & 433 & 433 & 433 & 433 & 433 \\
\hline
\end{tabular}

Note:* $p<0.10,{ }^{* *} p<0.05,{ }^{* * *} p<0.01$. Standard errors (in parentheses) are clustered on the matched-pair level. The interaction terms are dummies that take the value of one if a plant's value exceeds the median, and zero otherwise.

The individual inclusion of pre-treatment variables serves to identify potential effect modifiers, but the coefficients may reflect the effect of more than one determinant since the pre-treatment dummies are correlated. For example, plants with high pre-treatment emissions also tend to sell more offsets and generate more revenue. To address this, we 
jointly include those variables for which the interaction terms are individually significant at $\mathrm{p}<0.2$. The results from this joint regression are shown in columns (8) and (9), after keeping only the significant interaction terms. The coefficients imply that the treatment effect varies with the level of generated offsets and revenue during the pre-treatment years.

This creates four groups within the treated plants, defined over their levels of overabatement and revenue in the pre-treatment period: HH (high offsets and revenue); HL (high offsets, low revenue); LH (low offsets, high revenue); and LL (low offsets and revenue). The level of revenue and over-abatement are not strongly correlated, such that the treated plants are quite evenly distributed across these four groups.

The treatment effect for the LL group is given by the coefficient on the $\mathrm{DiD}$ term alone, which is positive and statistically significant. The effect for the HL group consists of the sum of the coefficient on the DiD term and the coefficient on the offset interaction term; the effect for the LH group is the sum of the coefficient on DiD and the interaction term with revenue; and the effect on the HH group is formed by the sum of all three coefficients. The treatment effect significantly different from zero only for the LL group ${ }^{18}$

If larger firms (in terms of revenue and over-abatement during 2008-2012) find it easier to cut emissions, as is intuitive, then our results can be interpreted as follows: We find a positive treatment effect for those plants that are most similar to the control plants. However, this effect is compensated by size, such that the average treatment effect is zero.

Another interpretation of our results is the following: Firms do respond to financial incentives for abatement, but there are reasons other than the level of the financial incentive that induce firms to reduce their emissions. For example, some firms may want to develop (or maintain) a "green" image, which could lead them to value emission abatement in its own right. As a consequence, they engage in abatement in excess of equating their marginal abatement costs with the allowance price. The extent of offsets generated by over-abatement during the pre-treatment phase could proxy for such green preferences. In other words, firms that abated emissions beyond their intensity targets during 20082012 continue to do so under the EHS regime, whereas those that just did the minimum

\footnotetext{
${ }^{18}$ For group HL, the treatment effect (with standard error in parenthesis) is 0.093 (0.132). For groups $\mathrm{LH}$ and $\mathrm{HH}$, the corresponding values are 0.134 (0.132) and -0.169 (0.191), respectively.
} 
respond to the lower financial incentive in the EHS by reducing their abatement effort.

\section{Conclusions}

In this paper, we estimate the differential impact of the nonEHS program vs. the CH EHS in terms of emissions reductions. We find that the two programs achieve similar levels of abatement on average, despite quite different marginal incentives. At the same time, the programs differ substantially with respect to their effect on public revenue. Both programs are associated with administrative costs and foregone revenue from the $\mathrm{CO}_{2}$ levy (because of the exemption), but the nonEHS program requires additional government revenue to finance the abatement subsidy. This leads to a second-order inefficiency, as the subsidy payments have to be raised via the general tax system and thus create a deadweight loss. Our results thus indicate that moving plants from the $\mathrm{CH}$ EHS into the nonEHS system would increase the overall program cost without leading to more abatement.

The inclusion threshold for the CH EHS is identical to that in the EU ETS and therefore difficult to change, but there is an ongoing political debate in Switzerland about expanding the nonEHS at the expense of the $\mathrm{CO}_{2}$ levy. This could be implemented by lowering the inclusion threshold in terms of annual emissions. As we are comparing the nonEHS program with the CH EHS, our empirical results do not directly speak to the consequences of expanding the nonEHS in this way. However, to the extent that a tax and an EHS are qualitatively similar policy instruments, we would expect that a tax of CHF 96 per $\mathrm{tCO}_{2}$ performs no worse in terms of abatement than the CH EHS, and therefore (by implication of our findings) than the nonEHS program. This is true a fortiori given that the tax is scheduled to increase further in the future. Based on this indirect comparison, our results suggest that expanding the nonEHS program at the expense of the levy will lead to higher societal costs without resulting in lower emissions.

An important caveat for our analysis is the small sample size, which results in large standard errors. We cannot exclude the possibility that the nonEHS program reduced emissions by, say, 5 percentage points more than the CH EHS. Also, we do find a positive treatment effect for the smallest EHS plants, which are most comparable to the 
nonEHS plants. Having said this, our point estimates imply a negative average treatment effect on emissions, which can probably be explained by a positive correlation between (proportional) abatement and firm size.

One of the advantages of market-based instruments (such as taxes and cap-and-trade systems) is that they do not require individual information about firms' abatement costs, which tend to be private. The nonEHS program in Switzerland, on the other hand, very much relies on firm-specific information when defining the plant-specific measures and targets. Due to its design, the current system provides incentives for plants to over-state their abatement costs. Such a strategy would enable firms to cheaply over-achieve their plant-specific goals and be compensated for this at a rate of $\mathrm{CHF} 100 / \mathrm{tCO}_{2}$. We have no way of determining whether plants indeed mis-represented their abatement opportunities (and if so, by how much); we merely note that the program provides an incentive for the strategic use of private information, which is absent in a tax or permit system. On the other hand, a command-and-control approach could potentially be more effective to decarbonize the economy than a tax or an ETS if sufficiently stringent targets are set. However, we can only speculate about whether a "zero emissions" policy via commandand-control would be politically feasible.

Lastly, there is also a redistributive aspect to our findings. Exempting firms from a $\mathrm{CO}_{2}$ tax (or an ETS with auctioning) shifts the incidence of climate policy towards households and the non-exempt firms. This is not equitable and, as implied by our research, neither is it likely to lead to more abatement. Whereas our econometric analysis is specific for Switzerland, we believe that our results could be valuable also for other countries that have to choose between subsidies and cap-and-trade systems (or taxes), in the pursuit of an equitable and effective climate policy.

\section{References}

Betz, R., T. Leu, and R. Schleiniger (2015). Disentangling the Effects of Swiss Energy and Climate Policies. ZHAW Zürcher Hochschule für Angewandte Wissenschaften, SML Working Paper No.5. 
Bian, J. and X. Zhao (2020). Tax or subsidy? an analysis of environmental policies in supply chains with retail competition. European Journal of Operational Research 283(3), $901-914$.

Brannlund, R. and L. Persson (2012). To tax, or not to tax: preferences for climate policy attributes. Climate Policy 12(6), 704-721.

Carattini, S., M. Carvalho, and S. Fankhauser (2017). How to make carbon taxes more acceptable. London: Grantham Research Institute on Climate Change and the Environment, and Centre for Climate Change Economics and Policy, London School of Economics and Political Science.

Cherry, T. L., S. Kallbekken, and S. Kroll (2012). The acceptability of efficiency-enhancing environmental taxes, subsidies and regulation: An experimental investigation. Environmental Science \& Policy 16, 90-96.

Climate Cent Foundation (2013). Stiftung Klimarappen Abschlussbericht 2005-2013. Technical report.

Conrad, K. (1993). Taxes and subsidies for pollution-intensive industries as trade policy. Journal of environmental economics and management 25(2), 121-135.

Cropper, M. L. and W. E. Oates (1992). Environmental economics: a survey. Journal of economic literature 30(2), 675-740.

Ecoplan (2015). Wirkungsabschätzung CO2-Abgabe. Technical report, Ecoplan, EPFL and FHNW, commissioned by FOEN.

Ecoplan (2017). Wirkungsabschätzung CO2-Abgabe: Aktualisierung bis 2015. Technical report, Ecoplan, commissioned by FOEN.

EnAW (2019). Die Energie-Agentur der Wirtschaft in Zahlen: 2018. Technical report, Energie-Agentur der Wirtschaft. https://enaw.ch/wp-content/uploads/2019/09/ enaw_leistungsausweis__2018_DE_web.pdf. 
FOEN (2018). CO2-Abgabebefreiung ohne Emissionshandel. Ein Modul der Mitteilung des BAFU als Vollzugsbehörde zur CO2-Verordnung. Technical report, Federal Office of the Environment.

FOEN (2019a). Emissionen von Treibhausgasen nach revidiertem CO2-Gesetz und KyotoProtokoll, 2. Verpflichtungsperiode (2013-2020). Technical report, Federal Office of the Environment.

FOEN (2019b). Faktenblatt, 15. April 2019, CO2-Emissionsfaktoren des Treibhausgasinventars der Schweiz. Technical report, Federal Office of the Environment.

FOEN (2019). Überblick Emissionshandel für stationäre Anlagen 2013-2018. Technical report, Federal Office of the Environment.

Fowlie, M., S. P. Holland, and E. T. Mansur (2012). What do emissions markets deliver and to whom? Evidence from Southern California's NOx trading program. The American Economic Review 102(2), 965-993.

Galle, B. (2013). Carrots, sticks, and salience. Tax L. Rev. 67, 53.

Hintermann, B. and M. Zarkovic (2020). Carbon pricing in switzerland: A fusion of taxes, command-and-control, and permit markets. ifo Dice Report 18(I), 35-41.

Kamien, M. I., N. L. Schwartz, and F. T. Dolbear (1966). Asymmetry between bribes and charges. Water Resources Research 2(1), 147-157.

Krysiak, F. C. and I. M. Oberauner (2010). Environmental policy à la carte: Letting firms choose their regulation. Journal of Environmental Economics and Management 60(3), $221-232$.

Landis, F. (2019). Cost distribution and equity of climate policy in switzerland. Swiss Journal of Economics and Statistics 155(1), 11.

Nault, B. R. (1996). Equivalence of taxes and subsidies in the control of production externalities. Management Science 42(3), 307-320. 
SFAO (2017). Evaluation der Lenkungswirkung des Emissionshandelssystems - Bundesamt für Umwelt. Technical report, Swiss Federal Audit Office, commissioned by FOEN.

TEP Energy (2016). Wirkungsabschätzung CO2-Abgabe auf Brennstoffe - Direktbefragungen zur Abschätzung der Wirkung der CO2-Abgabe auf Unternehmensstufe. Technical report, TEP Energy and Rütter Soceco, commissioned by FOEN.

Wagner, U. J., M. Muûls, R. Martin, and J. Colmer (2014). The causal effects of the European Union Emissions Trading Scheme: evidence from French manufacturing plants. In Fifth World Congress of Environmental and Resources Economists, Istanbul, Turkey. Citeseer.

Weitzman, M. L. (1974). Prices vs. quantities. The review of economic studies 41(4), $477-491$. 


\section{A Additional Tables and Figures}

Figure A.1: Event study graph with the year 2012 included

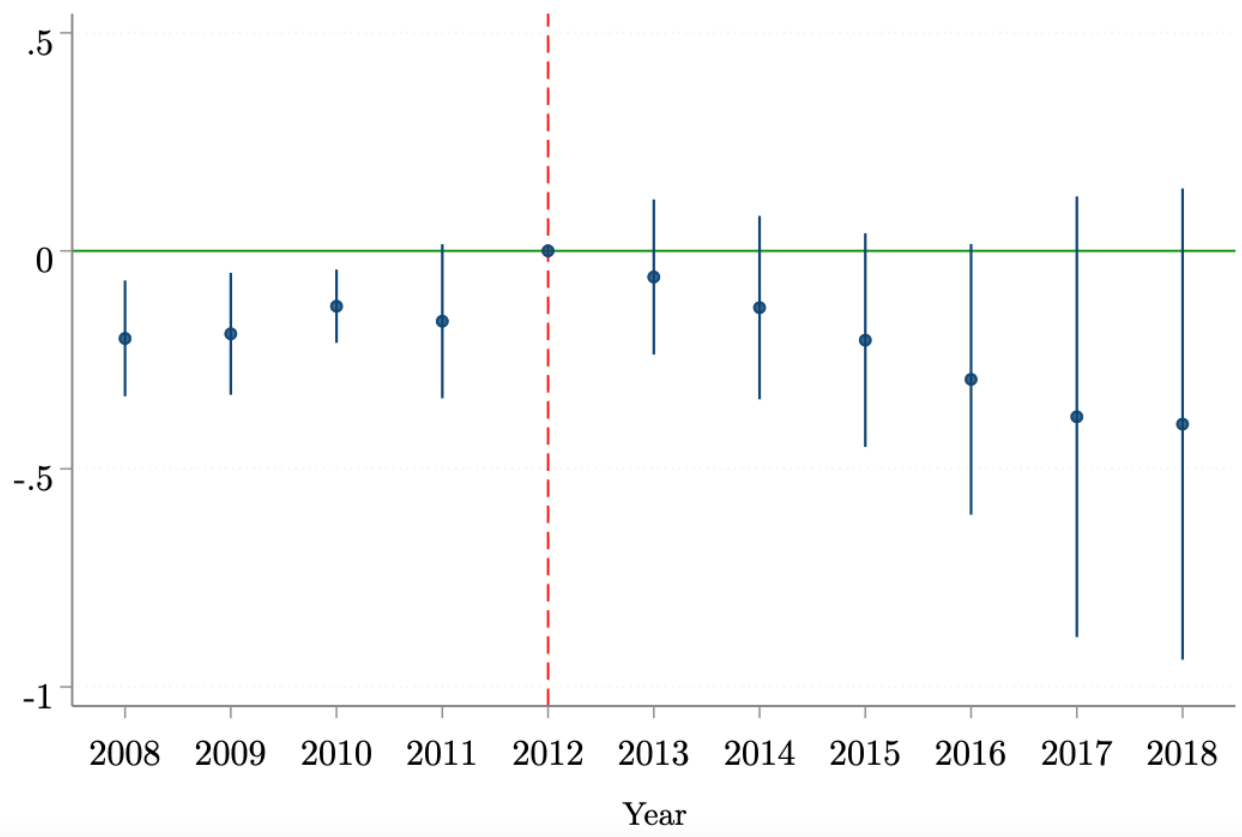

Table A.1: $\mathrm{CO}_{2}$ levy and fuel prices, 2008-2018

\begin{tabular}{|c|c|c|c|c|c|c|c|c|}
\hline & & Unit & 2008 & 2009 & 2012 & 2014 & 2016 & 2018 \\
\hline $\mathrm{CO}_{2}$ levy & & {$[\mathrm{CHF} / \mathrm{tCO} 2]$} & 12 & 24 & 36 & 60 & 84 & 96 \\
\hline Heating oil EL & $\begin{array}{l}\text { Market price } \\
\mathrm{CO}_{2} \text { surcharge }\end{array}$ & {$[\mathrm{CHF} / \mathrm{kg}]$} & $\begin{array}{l}0.990 \\
0.038 \\
\end{array}$ & $\begin{array}{l}0.560 \\
0.076 \\
\end{array}$ & $\begin{array}{l}0.894 \\
0.114 \\
\end{array}$ & $\begin{array}{l}0.766 \\
0.190 \\
\end{array}$ & $\begin{array}{l}0.385 \\
0.265 \\
\end{array}$ & $\begin{array}{l}0.612 \\
0.303 \\
\end{array}$ \\
\hline Natural gas & $\begin{array}{l}\text { Market price } \\
\mathrm{CO}_{2} \text { surcharge }\end{array}$ & {$[\mathrm{CHF} / \mathrm{kg}]$} & $\begin{array}{l}0.519 \\
0.032\end{array}$ & $\begin{array}{l}0.240 \\
0.064\end{array}$ & $\begin{array}{l}0.394 \\
0.096\end{array}$ & $\begin{array}{l}0.334 \\
0.160\end{array}$ & $\begin{array}{l}0.201 \\
0.224\end{array}$ & $\begin{array}{l}0.347 \\
0.256\end{array}$ \\
\hline Hard coal & $\begin{array}{l}\text { Market price } \\
\mathrm{CO}_{2} \text { surcharge }\end{array}$ & {$[\mathrm{CHF} / \mathrm{kg}]$} & $\begin{array}{l}0.158 \\
0.028 \\
\end{array}$ & $\begin{array}{l}0.076 \\
0.057\end{array}$ & $\begin{array}{l}0.087 \\
0.085 \\
\end{array}$ & $\begin{array}{l}0.069 \\
0.142 \\
\end{array}$ & $\begin{array}{l}0.058 \\
0.198\end{array}$ & $\begin{array}{l}0.090 \\
0.227\end{array}$ \\
\hline Propane & $\begin{array}{l}\text { Market price } \\
\mathrm{CO}_{2} \text { surcharge }\end{array}$ & {$[\mathrm{CHF} / \mathrm{kg}]$} & $\begin{array}{l}0.836 \\
0.036\end{array}$ & $\begin{array}{l}0.510 \\
0.072\end{array}$ & $\begin{array}{l}0.811 \\
0.108\end{array}$ & $\begin{array}{l}0.617 \\
0.179\end{array}$ & $\begin{array}{l}0.286 \\
0.251\end{array}$ & $\begin{array}{l}0.532 \\
0.287\end{array}$ \\
\hline
\end{tabular}

Sources: Thomson Reuters and FOEN $(2019 b)$ 
Table A.2: Industry classification of the full and matched samples

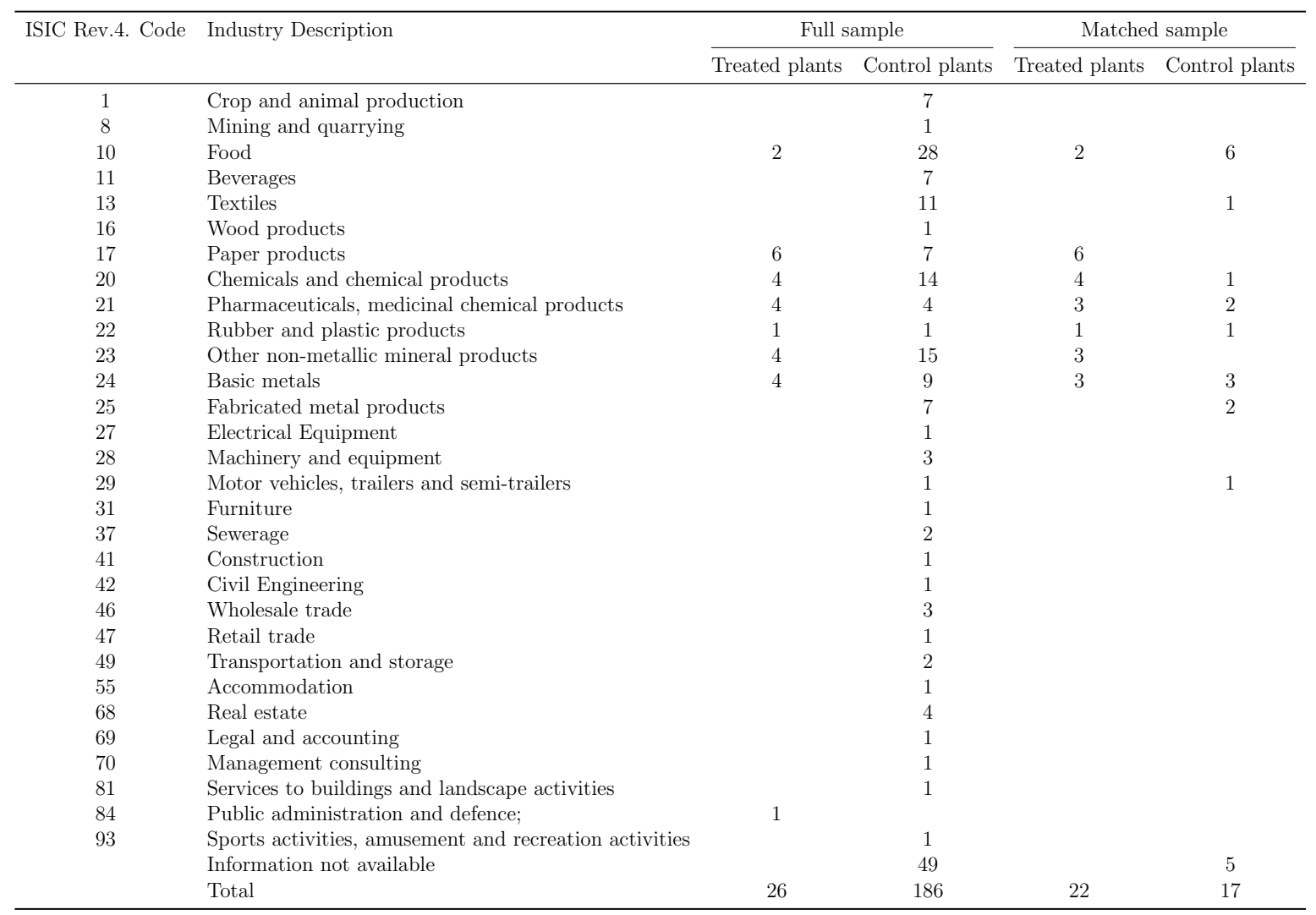

Table A.3: Heterogeneous treatment effects without matching

\begin{tabular}{|c|c|c|c|c|c|c|c|c|c|}
\hline \multirow[t]{2}{*}{ Dependent Variable: } & \multicolumn{9}{|c|}{ Emissions in tons of $\mathrm{CO} 2$ in logs } \\
\hline & (1) & (2) & (3) & (4) & (5) & (6) & (7) & (8) & (9) \\
\hline $\mathrm{DiD}$ & $\begin{array}{c}-0.114 \\
(0.674)\end{array}$ & $\begin{array}{c}0.096 \\
(0.558)\end{array}$ & $\begin{array}{c}-0.210 \\
(0.373)\end{array}$ & $\begin{array}{c}0.213^{* *} \\
(0.037)\end{array}$ & $\begin{array}{l}0.174^{*} \\
(0.053)\end{array}$ & $\begin{array}{c}0.070 \\
(0.401)\end{array}$ & $\begin{array}{c}-0.036 \\
(0.801)\end{array}$ & $\begin{array}{c}0.180 \\
(0.277)\end{array}$ & $\begin{array}{c}0.169 \\
(0.318)\end{array}$ \\
\hline DiD x Offsets & $\begin{array}{l}0.086 \\
(0.762)\end{array}$ & & & & & & & $\begin{array}{c}0.162 \\
(0.637)\end{array}$ & $\begin{array}{c}0.088 \\
(0.745)\end{array}$ \\
\hline DiD x Emissions ave. & & $\begin{array}{c}-0.334 \\
(0.221)\end{array}$ & & & & & & $\begin{array}{c}-0.191 \\
(0.590)\end{array}$ & \\
\hline DiD x Emissions trend & & & $\begin{array}{c}0.275 \\
(0.330)\end{array}$ & & & & & & \\
\hline DiD x Revenue & & & & $\begin{array}{c}-0.529 * * \\
(0.040)\end{array}$ & & & & $\begin{array}{c}-0.439^{*} \\
(0.068)\end{array}$ & $\begin{array}{c}-0.529^{* *} \\
(0.042)\end{array}$ \\
\hline DiD x Capital & & & & & $\begin{array}{c}-0.456^{*} \\
(0.080)\end{array}$ & & & & \\
\hline DiD x Employment & & & & & & $\begin{array}{c}-0.263 \\
(0.317)\end{array}$ & & & \\
\hline DiD x Cantonal Regulation & & & & & & & $\begin{array}{l}-0.075 \\
(0.758)\end{array}$ & & \\
\hline Year FE & $\checkmark$ & $\checkmark$ & $\checkmark$ & $\checkmark$ & $\checkmark$ & $\checkmark$ & $\checkmark$ & $\checkmark$ & $\checkmark$ \\
\hline Plant FE & $\checkmark$ & $\checkmark$ & $\checkmark$ & $\checkmark$ & $\checkmark$ & $\checkmark$ & $\checkmark$ & $\checkmark$ & $\checkmark$ \\
\hline Obs. & 2066 & 2066 & 2066 & 2066 & 2066 & 2066 & 2066 & 2066 & 2066 \\
\hline
\end{tabular}


Table A.4: Heterogeneous treatment effect with nearest 1-neighbor matching

\begin{tabular}{|c|c|c|c|c|c|c|c|c|c|}
\hline \multirow[t]{3}{*}{ Dependent Variable: } & \multicolumn{9}{|c|}{ Emissions in tons of $\mathrm{CO} 2$ in $\operatorname{logs}$} \\
\hline & (1) & $(2)$ & $(3)$ & (4) & (5) & (6) & (7) & $(8)$ & (9) \\
\hline & & & & Nearest & -neighbor & matching & & & \\
\hline $\mathrm{DiD}$ & $\begin{array}{c}0.316^{* * *} \\
(0.007)\end{array}$ & $\begin{array}{c}0.288^{* *} \\
(0.025)\end{array}$ & $\begin{array}{c}0.071 \\
(0.595)\end{array}$ & $\begin{array}{c}0.267^{* *} \\
(0.046)\end{array}$ & $\begin{array}{l}0.228^{*} \\
(0.062)\end{array}$ & $\begin{array}{c}0.136 \\
(0.283)\end{array}$ & $\begin{array}{c}0.115 \\
(0.415)\end{array}$ & $\begin{array}{c}0.430^{* * *} \\
(0.001)\end{array}$ & $\begin{array}{c}0.424^{* * *} \\
(0.002)\end{array}$ \\
\hline DiD x Offsets & $\begin{array}{c}-0.317^{* *} \\
(0.022)\end{array}$ & & & & & & & $\begin{array}{l}-0.284^{*} \\
(0.057)\end{array}$ & $\begin{array}{c}-0.318^{* *} \\
(0.017)\end{array}$ \\
\hline DiD x Emissions ave. & & $\begin{array}{c}-0.285^{* *} \\
(0.043)\end{array}$ & & & & & & $\begin{array}{l}-0.090 \\
(0.523)\end{array}$ & \\
\hline DiD x Emissions trend & & & $\begin{array}{c}0.174 \\
(0.233)\end{array}$ & & & & & & \\
\hline DiD x Revenue & & & & $\begin{array}{l}-0.236 \\
(0.104)\end{array}$ & & & & $\begin{array}{l}-0.196 \\
(0.113)\end{array}$ & $\begin{array}{l}-0.237^{*} \\
(0.077)\end{array}$ \\
\hline DiD x Capital & & & & & $\begin{array}{l}-0.150 \\
(0.346)\end{array}$ & & & & \\
\hline DiD x Employment & & & & & & $\begin{array}{c}0.046 \\
(0.768)\end{array}$ & & & \\
\hline DiD x Cantonal Regulation & & & & & & & $\begin{array}{c}0.092 \\
(0.464)\end{array}$ & & \\
\hline Year FE & $\checkmark$ & $\checkmark$ & $\checkmark$ & $\checkmark$ & $\checkmark$ & $\checkmark$ & $\checkmark$ & $\checkmark$ & $\checkmark$ \\
\hline Plant FE & $\checkmark$ & $\checkmark$ & $\checkmark$ & $\checkmark$ & $\checkmark$ & $\checkmark$ & $\checkmark$ & $\checkmark$ & $\checkmark$ \\
\hline Obs. & 383 & 383 & 383 & 383 & 383 & 383 & 383 & 383 & 383 \\
\hline
\end{tabular}

Note: ${ }^{*} p<0.10,{ }^{* *} p<0.05,{ }^{* * *} p<0.01$. Matching performed with replacement. Standard errors (in parentheses) are obtained through bootstrapping (500 replications).

Table A.5: Heterogeneous treatment effect with nearest 3-neighbor matching

\begin{tabular}{|c|c|c|c|c|c|c|c|c|c|}
\hline \multirow[t]{3}{*}{ Dependent Variable: } & \multicolumn{9}{|c|}{ Emissions in tons of $\mathrm{CO} 2$ in logs } \\
\hline & (1) & (2) & (3) & $(4)$ & $(5)$ & $(6)$ & (7) & (8) & (9) \\
\hline & & & & Nearest & -neighbor & natching & & & \\
\hline $\mathrm{DiD}$ & $\begin{array}{c}0.314 * * * \\
(0.003)\end{array}$ & $\begin{array}{c}0.286^{* *} \\
(0.021)\end{array}$ & $\begin{array}{c}0.068 \\
(0.545)\end{array}$ & $\begin{array}{c}0.264^{* *} \\
(0.030)\end{array}$ & $\begin{array}{c}0.225^{* *} \\
(0.045)\end{array}$ & $\begin{array}{c}0.134 \\
(0.178)\end{array}$ & $\begin{array}{c}0.110 \\
(0.399)\end{array}$ & $\begin{array}{c}0.428^{* * *} \\
(0.000)\end{array}$ & $\begin{array}{c}0.422^{* * *} \\
(0.000)\end{array}$ \\
\hline DiD x Offsets & $\begin{array}{c}-0.318^{* *} \\
(0.022)\end{array}$ & & & & & & & $\begin{array}{c}-0.285^{*} \\
(0.069)\end{array}$ & $\begin{array}{c}-0.319^{* *} \\
(0.013)\end{array}$ \\
\hline DiD x Emissions ave. & & $\begin{array}{c}-0.285^{*} \\
(0.050)\end{array}$ & & & & & & $\begin{array}{l}-0.090 \\
(0.526)\end{array}$ & \\
\hline DiD x Emissions trend & & & $\begin{array}{c}0.175 \\
(0.218)\end{array}$ & & & & & & \\
\hline DiD x Revenue & & & & $\begin{array}{l}-0.235 \\
(0.109)\end{array}$ & & & & $\begin{array}{l}-0.196 \\
(0.134)\end{array}$ & $\begin{array}{c}-0.236^{*} \\
(0.074)\end{array}$ \\
\hline DiD x Capital & & & & & $\begin{array}{l}-0.149 \\
(0.345)\end{array}$ & & & & \\
\hline DiD x Employment & & & & & & $\begin{array}{c}0.047 \\
(0.758)\end{array}$ & & & \\
\hline DiD x Cantonal Regulation & & & & & & & $\begin{array}{c}0.098 \\
(0.440)\end{array}$ & & \\
\hline Year FE & $\checkmark$ & $\checkmark$ & $\checkmark$ & $\checkmark$ & $\checkmark$ & $\checkmark$ & $\checkmark$ & $\checkmark$ & $\checkmark$ \\
\hline Plant FE & $\checkmark$ & $\checkmark$ & $\checkmark$ & $\checkmark$ & $\checkmark$ & $\checkmark$ & $\checkmark$ & $\checkmark$ & $\checkmark$ \\
\hline Obs. & 568 & 568 & 568 & 568 & 568 & 568 & 568 & 568 & 568 \\
\hline
\end{tabular}

Note: ${ }^{*} p<0.10,{ }^{* *} p<0.05,{ }^{* * *} p<0.01$. Matching performed with replacement. Standard errors (in parentheses) are obtained through bootstrapping (500 replications). 
Table A.6: Heterogeneous treatment effects with continuous variables

\begin{tabular}{|c|c|c|c|c|c|c|c|c|}
\hline \multirow[t]{3}{*}{ Dependent Variable: } & \multicolumn{8}{|c|}{ Emissions in tons of $\mathrm{CO} 2$ in logs } \\
\hline & (1) & $(2)$ & (3) & (4) & (5) & $(6)$ & $(7)$ & (8) \\
\hline & \multicolumn{8}{|c|}{ Matching without replacement } \\
\hline $\mathrm{DiD}$ & $\begin{array}{c}0.265^{* *} \\
(0.041)\end{array}$ & $\begin{array}{c}1.833^{* * *} \\
(0.002)\end{array}$ & $\begin{array}{c}0.108 \\
(0.369)\end{array}$ & $\begin{array}{l}1.163 \\
(0.209)\end{array}$ & $\begin{array}{l}0.510^{*} \\
(0.062)\end{array}$ & $\begin{array}{c}0.227 \\
(0.257)\end{array}$ & $\begin{array}{c}1.976^{* * *} \\
(0.008)\end{array}$ & $\begin{array}{l}1.307^{*} \\
(0.088)\end{array}$ \\
\hline DiD x Offsets $C$ & $\begin{array}{c}-0.029^{* *} \\
(0.045)\end{array}$ & & & & & & $\begin{array}{c}-0.022^{*} \\
(0.066)\end{array}$ & $\begin{array}{c}-0.029^{* *} \\
(0.032)\end{array}$ \\
\hline $\operatorname{DiD}_{\mathrm{x}}$ Emissions $_{C}$ & & $\begin{array}{c}-0.174^{* * *} \\
(0.006)\end{array}$ & & & & & $\begin{array}{c}-0.122^{* *} \\
(0.037)\end{array}$ & \\
\hline DiD x EmissionsDiff ${ }_{C}$ & & & $\begin{array}{c}0.031 \\
(0.940)\end{array}$ & & & & & \\
\hline DiD x Revenue $_{C}$ & & & & $\begin{array}{l}-0.088 \\
(0.243)\end{array}$ & & & $\begin{array}{l}-0.045 \\
(0.476)\end{array}$ & $\begin{array}{l}-0.087 \\
(0.166)\end{array}$ \\
\hline DiD x Capital $C$ & & & & & $\begin{array}{l}-0.049 \\
(0.158)\end{array}$ & & & \\
\hline $\operatorname{DiD}$ E Employment $C$ & & & & & & $\begin{array}{l}-0.022 \\
(0.523)\end{array}$ & & \\
\hline Year FE & $\checkmark$ & $\checkmark$ & $\checkmark$ & $\checkmark$ & $\checkmark$ & $\checkmark$ & $\checkmark$ & $\checkmark$ \\
\hline Plant FE & $\checkmark$ & $\checkmark$ & $\checkmark$ & $\checkmark$ & $\checkmark$ & $\checkmark$ & $\checkmark$ & $\checkmark$ \\
\hline Obs. & 433 & 433 & 433 & 433 & 433 & 433 & 433 & 433 \\
\hline
\end{tabular}

Note: ${ }^{*} p<0.10,{ }^{* *} p<0.05,{ }^{* * *} p<0.01$. Nearest-neighbor matching without replacement, as in Table 4. Standard errors (in parentheses) are clustered on the matched-pair level. 